\title{
Land and Sea Coordination: Revisiting Integrated Coastal Management in the Context of Community Interests
}

\author{
Wei Yuan (1) and Yen-Chiang Chang *(1) \\ School of Law, Dalian Maritime University, Dalian 116026, China; WeiYuanemail@yeah.net \\ * Correspondence: ycchang@dlmu.edu.cn
}

\begin{abstract}
At present, the ecological environment and resources of the global coastal zones are facing great pressures. Climate change leads to sea level rise, environmental change, stressful population increases and changes in demographics, all of which affect existing coastal management systems. Therefore, all coastal countries begin to increasingly attach importance to the integrated management of coastal zones. How to better adapt to current changes in global coastal zones is a question that every coastal country should think about. From sea- and land-partitioned management to land and sea coordination and from simple coastal management to the integration of the ecological environment and society, integrated management has been planned from many perspectives and levels. It plays a role in promoting the construction of a community with a shared future for mankind.
\end{abstract}

Keywords: integrated coastal management; land and sea coordination; ecological environment; ocean law; sustainable development

Citation: Yuan, W.; Chang, Y.-C.

Land and Sea Coordination:

Revisiting Integrated Coastal Management in the Context of Community Interests. Sustainability 2021, 13, 8183. https://doi.org/ $10.3390 /$ su13158183

Academic Editor: Zachary A. Smith

Received: 6 June 2021

Accepted: 20 July 2021

Published: 22 July 2021

Publisher's Note: MDPI stays neutral with regard to jurisdictional claims in published maps and institutional affiliations.

Copyright: (c) 2021 by the authors. Licensee MDPI, Basel, Switzerland. This article is an open access article distributed under the terms and conditions of the Creative Commons Attribution (CC BY) license (https:// creativecommons.org/licenses/by/ $4.0 /)$.

\section{Introduction}

A coastal zone is a zone where the land, sea and atmosphere intersect. Due to rich material resources, human development and construction, maritime transportation, fishery and aquaculture have progressed in these areas [1]. In the 21st century, population migration from inland areas to coastal zones has increased not only in developed countries but also developing countries. Populations and economies converging towards the sea will inevitably increase pressure on the coastal zones and their resources and aggravate the problems of the overuse of marine resources, loss of biological habitats and water pollution. The coastal zone has become the most densely populated area in the world, with the highest degree of development and utilisation and the most fragile ecological environment. In order to protect the coastal environment and promote its sustainable development, it is necessary to implement mechanisms to meet and manage its challenges. In last 50 years, the integrated coastal management (ICM) method has been generally adopted by coastal countries to effectively deal with and sustainably develop the coastal zone.

The concept of "land and sea coordination" was first proposed in China at the beginning of the 21st century. The concept is derived from the idea of "sea-land integration". Compared with ICM, land and sea coordination has a larger actual implementation area and richer implementation means. ICM aims to put economic development and coastal ecosystem protection in equally important positions and focuses more on the realisation of ecological growth. On the other hand, land and sea coordination is more inclined to aid in the economic development of coastal areas and pays more attention to the realisation of social growth. Therefore, the main intent of land and sea coordination is to guide and solve coastal resource allocation and management problems intelligently.

At present, the development of the integrated coastal zone is not balanced. Developed countries have reached a relatively high overall governance level due to their strong economic strength, relatively small populations, and well-developed systems. However, the developing countries have been unable to implement because of various constraints [2]. 
The existing problems of ICM are still relatively prominent. In view of the theoretical orientation of ICM and the practices of various countries, the academic community has conducted systematic research on ecological perspectives and social relations [3]. Faced with the lack of top-down guiding ideology in coastal zone management, it is worth further exploration of how to use land and sea coordination as the theoretical foundation for practices, and to find an excellent management method that will improve laws and regulations, improve law enforcement efficiency and enhance public participation, thereby benefiting the whole world.

\section{The Relationship between Integrated Coastal Management and the Overall Planning of Land and Sea \\ 2.1. Concept of Coastal Zone}

A coastal zone is a geographic unit that connects ocean systems and land systems and connects to human survival and development [4]. Scholars believe that the scope of a coastal zone depends on its purpose, which varies with different management responsibilities [5]. In order to achieve the goals of a management plan, all land affected by the sea and all coastal waters affected by the land are included, which also includes coastal river basins, extending for hundreds of kilometres inland and extending to the edge of the continental shelf at sea [6].

\subsection{Concept of Coastal Zone Management}

As early as the 1930s, American experts first put forward the concept of ICM [7]. With the development of society, the connotation of ICM began to change. ICM refers to the coordination, supervision and management of space, resources and ecological environments and governmental development and utilisation through planning, legislation, law enforcement and supervision in order to achieve the sustainable utilisation of coastal zones. Through planning and project development, future-oriented resource analysis and sustainable concepts should be applied to test each stage of development, with the goal of preserving resources in coastal areas [8].

\subsection{Purpose and Tasks of Integrated Coastal Zone Management}

The main purpose and tasks of ICM are to protect the health of the marine environment and to utilise and sustain marine resources. It concerns itself with how to prevent and solve the problems of marine ecological environment change in the face of natural disasters; it also concerns itself with how to plan the economic development of coastal and land areas, and how to develop and manage the social economy, etc. [9]. Chinese scholars believe that ICM, as a continuously enriched and maturing management practice, is a full practice of land and sea coordination strategy [10]. Even though there are still some differences in opinion between researchers at home and abroad on the hierarchical relationship between ICM and the land and sea coordination, it must be admitted that there are similarities between the two and they promote each other in development.

The concept of land and sea coordination is similar to the concept of ICM, but not exactly the same, and they influence each other. China proposed the concept of land and sea coordination, which borrowed from the core idea of ICM and sublimated it, shifting the focus from the coastal environment to the economy of the entire coastal region. Because ICM has been developed for a long time, its means of implementation are richer than land and sea coordination, and it is more mature in terms of legislation, law enforcement, evaluation and supervision. 


\section{Current Problems in Integrated Management of Coastal Zones}

\subsection{Insufficient Legal Basis}

Effective coastal zone management requires laws and regulations. In this regard, developed countries such as some European countries and the United States have put relevant coastal zone management laws into action as early as the 1970s [11]. After years of development in terms of prevention, protection, evaluation, punishment and other aspects, a complete legal system has been formed [12]. However, some developing countries have not yet promulgated targeted coastal zone management laws due to late starts and complex national conditions. This leads to a serious imbalance in the standards of coastal zone management on a global scale. From the perspective of globalisation, the fundamental reason for this imbalance is a lack of unified legal norms.

For example, compared with Western developed countries, China started its research on ICM very late. Since the proposal on formulating the Coastal Zone Management Law in 1979, China has not yet successfully promulgated a national and integrated Coastal Zone Management Law. In addition, there are some conflicts between China's domestic law and international law. For example, according to the United Nations Convention on the Law of the Sea (UNCLOS) and other international laws concerning the sovereignty of resources in sea areas under national jurisdiction, sea areas are owned by the state. China's Constitution stipulates that natural resources such as tidal flats belong to the state. However, according to the Regulations for the Implementation of the Land Administration Law, woodland, grassland, wasteland, tidal flats and other land not owned by the collective shall be owned by state. Based on the above-mentioned laws and regulations, when tidal flats belong to sea areas, they belong to the state. When tidal flats belong to land, they may be owned by either the state or the collective. Thus, in the Chinese law, the boundary is not clear as to whether tidal flats belong to land or sea [13].

\subsection{Law Enforcement Equipment and Efficiency}

Within the jurisdiction of a country, law enforcement agencies usually deal with violations and crimes. However, in developing countries, the development of maritime law enforcement forces is relatively insufficient, and law enforcement equipment is not yet adequate; these things need to be further improved. There are many national marine law enforcement departments with overlapping functions and decentralised law enforcement. The quality of law enforcement personnel needs to be improved, and there are defects in law enforcement methods and procedures. In ICM, the above-mentioned problems and contradictions will become more prominent due to the many administrative departments and maritime laws involved, driven by the interests of various industries [14].

Looking around the world, there is no law enforcement agency with absolute authority in the international community. The implementation of international law can only be determined based on its legitimacy and significance to the international community. Under this common presumption, those international norms that can best demonstrate the common interests of the international community will have higher "effectiveness" in their actual implementation. However, in many maritime countries, the economic development is uneven. Many countries develop slowly and invest much less in ICM than that of developed countries. Therefore, the effect of law enforcement is bound to be unsatisfactory.

\subsection{Lack of Public Participation}

The current ICM policies of most countries emerge from government-led thinking systems; coastal residents and fishermen, etc., are not widely involved, which leads to the inability to prioritise the demands of local residents when formulating policies. It is precisely because of the low level of public participation that the formulated policies may encounter considerable resistance in the later implementation process. The law is a tool to serve the society, but the essence of society is the people's sense of identity [15]. Therefore, a system lacking that foundation will reduce the scientific nature and rationality of the system on some level. 


\section{Analysis of National Practice under the Land and Sea Coordination}

This section deals with the aspect of laws and regulations. For example, the different national conditions that lead to laws and regulations of each country have different formulations in terms of main body and content. In the development of ICM in Europe and America, developed countries have a very long history of such laws and the relevant regulations are somehow concrete. In contrast, ICM in China has a rather short history, so the content of the regulations is more dispersive and mainly focuses on the development of local measures. Although China is short of specific laws to deal with ICM issues, it has made some efforts in the data collection regarding law enforcement and has made full use of the advantages of video surveillance systems to ensure full coverage of data in coastal zones. In terms of public participation, both the coastal tourism in Cambodia and community activities in Australia provide positive examples. It is observed in this section that only when coastal residents participate in management can the effectiveness of ICM be fundamentally guaranteed.

\subsection{State Practice to Improve Laws and Regulations}

Compared with the ICM developed by European countries for decades, China's legal support in this area is obviously weaker [16]. Since China has never issued a National Coastal Zone Management Law, some problems in the coastal zone can only be solved by referring to other similar laws. For example, in China, the Law on the Administration of Sea Areas promulgated in 2001 covers marine functional zoning, the right to use sea areas and the compensation systems for the use of sea areas [17]. The Law on Ports in 2003 also filled the legal gap in port management, and the Port Law has so far undergone three amendments in 2015, 2017 and 2018, respectively [18]. The Notice of the State Oceanic Administration on Issuing the Measures for the Protection and Utilization of Coastlines was issued by the Former State Oceanic Administration in 2017 [19]. The legal deficiencies have been adjusted by these national laws, which have made up for the ICM national legislative gap to some extent. Moreover, coastal provinces can supplement the legislation according to their own conditions. For example, on 27 September 2019, the 14th meeting of the Standing Committee of the 13th People's Congress of Shandong province approved the Regulations on the Protection of Coastal Zone in Dongying City [20]. Dongying is the second largest petroleum industry base in China. The Regulations focus on the supervision of key areas such as oil and gas exploitation and set forth requirements for oil and gas exploration and development projects in Dongying. Accordingly, the plan should be formulated according to the duration of the mining rights so that the existing oil and gas development projects in the key protection areas exit in an orderly way; in general, environmental impact assessment should be conducted for oil and gas exploration and development projects in the protection areas, environmental protection equipment and emergency equipment should be equipped in accordance with standards and regulations, environmental risk assessments should be carried out regularly, emergency drills should be strengthened and potential environmental accidents should be eliminated. At the same time, the principle should be stipulated on how to dispose of the pollutants produced by oil and gas exploration and development in the coastal zone [21].

Similar regulations are also made in other provinces. For example, Zhoushan City of Zhejiang Province issued the Administrative Regulations of Zhoushan National Marine Special Reserve in 2016 [22], and the Guangxi Zhuang Autonomous Region issued the Regulations on the Protection of Uninhabited Islands in 2016, among other local regulations [23]. Although coastal zone management laws and regulations in coastal provinces are still relatively scattered and the coastal zone has not been legislated as a holistic environmental unit (it is impossible to unify laws and regulations to coordinate and supervise the coastal zone's space, resources, ecological environment and its development and utilisation), these places have accumulated valuable experience in formulating special legislation at the national level. 
In 1972, the United States enacted the Coastal Zone Management Act. It is an important milestone in the marine field, and it is also the first integrated marine management law in the world [24]. After that, along with development, the Continental Shelf Land Act was successively revised and many laws such as National Environmental Policy Act, the National Marine Pollution Planning Act and the Fisheries Protection and Management Act were formulated, forming a relatively complete ICM legal system. The act has played a positive role in effectively controlling the excessive development of the coastal zone and continuous deterioration of the environment [25]. The relevant laws of coastal zones in the United States are relatively complete, which can control the process and effects of coastal zone development and governance more effectively.

Although the United States has enacted the Coastal Zone Management Act, the collaboration among federal, state and local entities has not yet been institutionalised. For example, California's Coastal Law and other state and federal laws indicate that the roles [26], responsibilities and privileges of different levels of government across states are overlapping and require frequent coordination [27]. Therefore, even if the laws are in the same country, more coordination is needed to achieve the high effectiveness [28].

The UK has also made efforts in terms of ICM for a long time. Before the promulgation of the Marine and Coastal Access Act [29], the UK used many cross-cutting laws and regulations to restrict marine development activities. However, this decentralised management system gradually exposed its shortcomings. More and more problems are emerging, which is mainly reflected in the ambiguity of the powers and responsibilities of various institutions and low government management efficiency under this system, which directly affects the advancement of marine development and utilisation activities.

The Marine and Coastal Access Act was promulgated in 2009 after several years of discussions and consultations among government departments, non-governmental organisations and all sectors of society. The law upholds the consistent concept of comprehensive governance and the original intention of encouraging the sustainable development of the ocean and detailed planning from eleven angles. For example, the Marine Management Organisation has been set up to plan maritime areas in detail and implements the United Nations Convention on the Law of the Sea.

\subsection{National Practice to Improve the Efficiency of Law Enforcement}

Dongying in Shandong Province, with a coastline length of $413 \mathrm{~km}$, is the central city of the Yellow River Delta, located at the intersection of the Yellow River Delta Efficient Ecological Economic Zone and the Shandong Peninsula Blue Economic Zone [30]. It has the youngest coastal wetland in China, and the second largest oil industry baseShengli Oilfield in China. In 2005, Dongying joined the PEMSEA's SDS-SEA Sustainable Development Strategy Project, as the experimental site of ICM Programme. One of the important steps for the success of Dongying ICM is to ensure the establishment and operation of an efficient inter-agency coordination mechanism. To this end, Dongying National Task Force (NTF) set up an inter-departmental coordination committee in 2010 to reduce inter-agency or inter-department conflicts and reduce the inefficient use of financial resources, thereby greatly improving the efficiency of management.

In terms of implementation, in order to vigorously promote coastal zone restoration projects and solve the prominent problem of coastal zone ecosystem degradation, Dongying has issued detailed government regulations, known as the Dongying Bohai Integrated Management on Detailed Implementation Plan for Ecological Restoration Project. It is also conducive to the implementation of integrated management in place from the details. The project implemented the removal of abandoned ponds in the reclaimed wetland marine ecological restoration project area in Kendong Xiansui Gou and completed the reclaimed wetland restoration of 478 hectares, renovating and rehabilitating the shoreline of 4 kilometres; in the coastal wetland ecosystem restoration project area on the north side of Xiaodao River, 60.27 hectares of abandoned ponds were removed and restored to wetlands. The Yongfeng River-Xiaodao River Bank Ecological Restoration Project completed the 
restoration of 7.6 hectares, and completed the first planting of Suaeda salsa vegetation, covering an area of more than 1800 hectares [31].

In terms of operational supervision, Dongying has built a video monitoring system for key sea areas, which can conduct video surveillance on key sea areas such as oil and gas, wharves, fishing ports, seawalls etc., with a monitoring radius of $15 \mathrm{~km}$. Through the network, administrative departments at all levels can check the current situation of the sea area under their jurisdiction anytime, and transmit video wirelessly in the coastal areas without semaphore resources (such as Chengdong Seawall of Dongying and Guangrao Seawall). Dongying Ocean and Fishery Administration purchased one set of shore-based radar equipment, agreed to share one set with the North Sea Monitoring Center of the State Oceanic Administration, and agreed to share six sets with Dongying Border Defense Detachment, and a total of 8 sets of shore-based radar equipment, and built a shore-based $\mathrm{X}$-band radar monitoring system to carry out marine oil spill detection, ship identification, etc. [32].

In the global view, in the absence of a unified law enforcement agency in the international community, how to effectively improve the law enforcement is the goal of the joint efforts of all countries. Through the case of Dongying, it can be analysed to increase investment in the following ways: first, to increase investment and improve the law enforcement equipment. Building of large-scale and advanced marine patrol ships and aircraft can further strengthen the construction of marine surveillance network, and accelerate the satellite and ground data transmission network, wireless video transmission systems between ships and aircraft, data centre, etc. Second is to further clarify and coordinate the responsibilities and division of labour of law enforcement teams to avoid repeated law enforcement. Third is to improve the maritime law enforcement supervision, conflict resolution mechanism and emergency response mechanism. Fourth, the successful law enforcement experience of some developed countries shows that building of a multi-functional marine law enforcement team can improve the efficiency of law enforcement and avoid the waste of manpower, material and financial resources [33].

\subsection{National Practice to Increase the Participation of Coastal Residents}

The impact of ICM on the livelihood of coastal residents is more obvious than that on inland residents. ICM emphasises an overall plan, reflecting not only the impact on the ecological environment of coastal zones, but also the impact on social environments [34]. The impact of ICM on coastal cities penetrates all aspects of residents' life.

Most of the world's coastal cities are areas with relatively developed tourism, so the beach tourism will change as management methods adjust. Beach management in Sihanoukville, Cambodia, provides a good example.

As early as 2004, Ochheuteal beach was occupied by randomly separated sheds. The land around it was mainly used as a parking lot, a temporary garbage dump, and a temporary toilet facility. These facilities lacked proper wastewater treatment links, and the wastewater was discharged directly into the ground. As a result, the overall environment of the beach is chaotic. To solve the beach problem, an integrated tourism development and management plan was launched, mainly from the perspective of zoning planning. PEMSEA provided technical assistance and $4.6 \%$ of the financial support for the entire project, the government provided $27 \%$ and the remaining funds were donated by the vendors. Through a series of zoning management efforts, the effect of the beach environment management is remarkable, and the beach attracts more and more tourists: 144,995 in 2004 and 1,327,748 in 2014. This increases the daily income of the vendors by USD 80 to USD 100. So, they invested an average of USD 20,000 in kitchens and sheds and expected to get a return within four to five years [35].

The successful case of Ochheuteal beach management shows that ICM has a great impact on the work and income of coastal residents. In the governance policy of Sihanoukville, not only the regional organisations and the government but also the local residents participate in promoting ICM in the form of investment first and then profit. This kind of 
local resident participation and use of the crowdfunding model to jointly invest in ICM can be extended to the world, especially to developing countries. Under the premise of limited funds, this model can solve the problem of governance funds to the greatest extent by making a joint investment and benefiting from it.

Unlike Cambodia's resident investment, Australia started by organising rich community activities, which also increased public participation [36]. In Victoria, through the National Coastal Action Plan, which started in 1995, community-based activities have received assistance and attention. Diving clubs manage reef health; coastal parks are responsible for weed control; Fishermen's Associations manage regional fishing, etc. [37]. Coastal conservation has set up a number of non-governmental voluntary organisations to implement coastal zone restoration, community education, management and protection plans. Most organisations cooperate with local councils or government agencies. Sponsoring groups include conservation groups, civic progress associations and local service groups [38].

\section{Integrated Coastal Management Measures under the Perspective of Land and Sea Coordination}

As can be seen from the above analysis on the practices of different countries, different solutions are put forward under different environmental conditions. However, although the practices of each country do not directly mention that they are under the guidance of land and sea coordination, the core ideas and practical measures of each country coincide with that theory. By analysing the practical cases in various countries, some excellent practices suitable for global promotion can be summarised.

\subsection{SOC Report}

Land and sea coordination is essentially a guiding ideology and strategic deployment for balancing the overall development of land and sea at the national macro level while dealing with the relationship between land and sea development. After this strategic deployment is implemented, regular reports are needed to evaluate the correctness of the deployment. According to the recommendation of ICM, the Dongying Municipal Government decided to prepare and make a State of Coast Report (SOC Report) to measure the input, output and results of the implementation of the plan and find the weaknesses, gaps and deficiencies in order to make improvements. The SOC is a comprehensive reporting system based on a range of performance indicators to identify changes in the socioeconomic and environmental conditions of a particular coastal area due to policy and management interventions. Therefore, it can be seen that the SOC report, as an effective summary of regular evaluation, can reflect the implementation of ICM to the greatest extent. The 2010 SOC selected a total of 32 performance indicators to identify the trends from 2005 to 2010. Among them, 13 reports are related to coastal management and the other 20 are related to sustainable development, such as the prevention and management of natural disasters, the conservation and management of ecosystems and the management of biodiversity, pollution, fisheries and aquaculture, etc. The evaluation report reflects the effect of ICM over a period of time from an objective perspective. As a basis for review, the value of the SOC report is obvious. Government organisations can make timely policy adjustments based on the situation reflected in the report [39].

In recent years, the Dongying Municipal Government has made corresponding planning and deployment efforts through different SOC reports at various levels. For example, in April 2020, three provincial-level Marine ranches were established in Lijin county, Kenli district and Hekou district [40]. These three Marine ranches can maximize the development and utilization of coastal zones and bring more economic benefits regardless of their geographical location or ecological environment. 


\subsection{Maritime Video Surveillance System}

From the perspective of land and sea coordination, it is necessary to actively obtain land and sea data and establish an increasingly complete database. Dongying adopts a combination of various forms of sea video monitoring through radar monitoring, video transmission, etc. to grasp of the status of the coastal zone in real time. This monitoring system can help relevant departments obtain first-hand data, so that they can develop a more scientific coastal zone management plan.

The use of maritime video surveillance can dynamically monitor the status of the jurisdictional sea area in real time. Using this technology, Dongying has carried out monitoring of oil platforms, ports, seawalls, etc. The marine stereo monitoring command vehicle has advantages for marine disaster emergency monitoring and is the first to be equipped in China. The command vehicle can realise business tasks such as data transmission, image processing, command and communication, etc. X-band radar is an effective means to monitor oil spills and sea ice. The X-band radar monitoring system built in Dongying is used for oil spill detection, ship recognition and other work. At present, coastal prefecturelevel cities in Shandong Province have accumulated successful technical experience in the application of the above-mentioned monitoring technology, which can be promoted and applied in coastal cities nationwide or even globally.

Since the Shengli oilfield is located in Dongying, more attention needs to be paid to oil spill accidents. If an oil spill is found, it can be dealt with in time, and the maritime video surveillance system can play a powerful role in monitoring oil spill accidents. For example, in 2011, the Penglai 19-3 oilfield's oil spill accident caused seawater pollution in the surrounding and northwestern area of about $6200 \mathrm{~km}^{2}$ (exceeding the Class I seawater quality standard), among which $870 \mathrm{~km}^{2}$ of seawater was seriously polluted (exceeding the Class IV seawater quality standard), and the highest concentration of petroleum in seawater (station) appeared on June 13, which exceeded the background value by 53 times. The polluted area reached $3750 \mathrm{~km}^{2}$ in late June 2011, the seawater and petroleum polluted area reached $4900 \mathrm{~km}^{2}$ in July and the seawater and petroleum pollution decreased to 1350 $\mathrm{km}^{2}$ in August. The seawater and petroleum pollution area around the Penglai 19-3 oilfield decreased significantly in September. At the end of December, there was still some sporadic oil film on the surface of the Penglai 19-3 oilfield [41]. On 22 November 2013, a deflagration accident occurred in the Sinopec Donghuang oil pipeline, which caused crude oil spill into the Jiaozhou Bay of Qingdao. The oil spill caused pollution to the marine environment of Jiaozhou Bay and the sea area around the mouth of the bay. The oil spill on the beach was obvious enough to be seen near Dashou in the Huangdao District. Oil films and oil spills were also found in parts of the water area of Qingdao [42].

\subsection{Demonstration Zone for Integrated Coastal Management}

The land and sea coordination regards the land and the ocean as two interdependent and interactive and indivisible systems and the content contained in it is comprehensive and extensive. Therefore, the establishment of an integrated demonstration area is conducive to the comprehensive layout of practical results. Dongying's ICM project is an integral part of the blue economy development in Shandong Province. Shandong Province has designated some areas to focus on and demonstrate creating an excellent coastal zone. In the South China Sea, an ICM demonstration area has been established. Through typical demonstrations, it will give a full play to the point-to-surface effect and promote the comprehensive development and management of coastal resources in the South China Sea. In 1997, the supporting project "ICM Capacity-building in the Northern South China Sea" was approved by the United Nations Development Programme (UNDP). The project aims at applying the sustainable development theory and ICM to improve the integrated coastal zone management capacities of developing countries and promote the development and utilisation of marine resources in developing countries [43]. Since the implementation of ICM capacity building in the northern part of the South China Sea, three ICM demonstration models have been established in three demonstration areas, namely: the sustainable 
development model of marine fishery resources in Hailing Bay in Yangjiang City, Guangdong Province; the port development and management model in Fangchenggang City, in the Guangxi Zhuang Autonomous Region; and the comprehensive utilisation management model of marine resources in Qinglan Bay, Wenchang City, in Hainan Province. Through the exploration of the ICM mechanism, the governments of the three demonstration zones have improved their understanding of ICM, and the staff have been trained, which greatly improved the comprehensive management of the demonstration zones and improved the comprehensive management and rational use of the resources of the South China Sea coast and the ability to protect the marine environment, bringing benefits and demonstration effects to the neighbouring regions [44].

\section{The Way Forward}

\subsection{Improve the Global Coastal Zone Management Plan}

ICM is not a job that pays off immediately; instead, it requires scientific planning and year-round persistence. ICM emphasises the coordination of multiple departments from multiple perspectives, focusing on the word "comprehensive". ICM is implemented through decentralised management of departments and industries. Conflicting policies from different departments make coordination between various departments difficult, prone to interest conflicts, overlapping functions and duplication. Only standing at an absolute height can better complete the overall planning.

From a global perspective, ICM needs relatively systematic planning, which should take into full account the different characteristics of the coastal zones of each country. As such, different management methods should be adopted. In Latin America, for example, the Andes mountains traverse the west coast, and most of them are cliff coasts, making the west coast availability for exploit extremely low compared with most of the island countries of South Asia which have coastlines and natural harbours. There must be a substantial difference when implementing ICM methods. Latin America should be more inclined to the development of the east coast, while the west coast focuses more on developing tourism [45]; South Asia can take advantage of the natural coastlines to vigorously develop the fishery and shipping industry.

\subsection{The Positive Effect of Integrated Coastal Zone Management on the Development of Legal System in the International Community}

The problems related to the coastal zone prompt countries to use scientific and comprehensive management methods, understanding the large ecosystems, in order to fundamentally change this situation. Legal means are undoubtedly the most effective [46].

As early as the 1930s, some countries enacted legislation to protect their coastlines. The United States, the pioneer of ICM special legislation, passed the Coastal Zone Management Act in 1972. In the early 1990s, the United States extended the scope of Coastal Zone Management Project to non-point source pollution that affects coastal water quality. These developments have provided the impetus for other countries to start implementing management systems that recognise the interrelationship between pollution and the environment [47]. Agenda 21 adopted by the United Nations Conference on Environment and Development (UNCED) formally includes ICM on the agenda of international organisations in Chapter 17. In particular, the United Nations Conference on the Human Environment held in 1972 guided ICM development with its comprehensive principles, although the focus of the conference was not on coastal zone management but on addressing the broader environmental policies and sustainable development goals [48]. The United Nations' organisations have also adopted the International Convention on the Prevention of Pollution from Ships (MARPOL), the Convention on the Prevention of Marine Pollution, the Dumping of Wastes and Other Matters and the International Convention on Wetlands as Waterfowl Habitat, etc.

ICM projects are not limited to developed countries. Many developing countries have implemented projects through the efforts of international organisations and non- 
governmental organisations. The International Food and Agriculture Organisation (FAO) and the World Meteorological Organisation (WMO) also advocate for ICM for different reasons. For example, the World Meteorological Organisation became involved in the ICM programme because of its concerns about climate change. Many developing countries also put forward a series of laws and regulations, which enriched the legal connotations of ICM [49].

Countries and international organisations are paying more and more attention to the legal management of coastal zones. The cultural and natural environment of coastal zones can be fundamentally improved through legal means. Therefore, ICM has played a positive role in the development of legal systems in the international community.

\subsection{The Integrated Coastal Management Plays a Promoting Role in Building a "Land and Sea Coordination"}

Human beings live and multiply on land. In early civilisations, convenient navigation on fishing boats and ships appeared. After all, they all extended from the land to explore the edge of the ocean. The concept of "land and sea coordination" is a change in how humans observe their living area, requiring researchers to abandon the limited landcentred vision and reflect on major issues in human history and reality. "Land and sea coordination" works to coordinate the central and local governments, coastal areas and inland areas. It is necessary to strengthen market measures such as ecological compensation and the differentiated management of land emission quotas to coordinate marine and terrestrial environmental governance policies and to clarify the distribution of interests and responsibilities between inland and coastal areas. "Land and sea coordination" is precisely the result of changes in human society and the enhancement of human capacity to develop and utilise the ocean. It links with the ocean to form a shared future for mankind, with distinct integrity and social organisation.

Global coastal zones are inseparable from each other, and ICM is an indispensable part in building a maritime community with a shared future. Although the coastal zones owned by countries vary in scope, each part is interconnected and affects the other. Starting with complex cooperative action, ICM explores the interrelation and interaction among humans, the land and the ocean. It studies and enriches the coordination of land and sea both practically and theoretically, in terms of time and space, as well as from the technical and institutional perspectives. It provides support for the planning and implementation of land and sea coordination. Under the premise of coordinated development, in order to solve the contradictions that arise between coastal resources and environment, an ICM development strategy is formulated to control human activities dynamically and continuously and reduce the impact on coastal areas so as to promote sustainable development of marine regional economies [50].

\section{Conclusions}

This paper shows that the concept and means of ICM in different regions are different [51]. The entire international community is paying increased attention to coastal zone issues. ICM is the symbiosis between human beings and their environment, playing an indelible role in enriching land and sea coordination. The idea of land and sea coordination could be promoted to the whole world with the right scientific management methods. Based on the analysis of multi-country practices and cases, this paper summarises ICM experiences that can be extended to the international community from various perspectives. These valuable experiences can better reflect the importance and operability of land and sea coordination and provide a wealth of theoretical support for the future development of global coastal zones.

First, improve laws and regulations. In terms of local provinces, targeted and detailed regulations should be formulated in accordance with different environments of each region; at the national level, basic laws should be formulated. Thereby, ICM can be better implemented only if there are laws in place, observed and strictly enforced, on an international level. This would help to unify and coordinate ICM globally. 
Second, improve the efficiency of law enforcement. Develop detailed ICM implementation plans for each area before enforcement. For law enforcement, a maritime video surveillance system can clearly and digitally control coastal environmental data in real time. Next, the SOC report should be carried out to summarise the operational results of this stage and make judgments for policy adjustments. Finally, the establishment of ICM demonstration area should be established to promote the successful experience to society.

Third, increase the participation of coastal residents in order to maximise participation in ICM of residents living in coastal zones. Do not only listen to residents' opinions in the legislative process; also let residents join as governance investors. Meanwhile, ICM activities in coastal communities should be increased to heighten residents' sense of responsibility and mission.

Author Contributions: Writing—original draft preparation, W.Y.; writing—review and editing, Y.-C.C. All authors have read and agreed to the published version of the manuscript.

Funding: This research was funded by China's National Social Sciences Foundation (18VHQ002); the Shenzhen Philosophy and Social Science Planning Project, "Research on the Legal Path of Market Integration in the Guangdong-Hong Kong-Macao Greater Bay Area", No. SZ2020B027; Economic and Social Development Research, Base General Project, Liaoning Province, China, "Research on the Legal Issues regarding Northeast Asian Energy Market Integration", No. 20211sljdybkt-005.

Institutional Review Board Statement: Not applicable.

Informed Consent Statement: Not applicable.

Data Availability Statement: Not applicable.

Acknowledgments: The field work is supported by the following projects: China's National Social Sciences Foundation (18VHQ002); the Shenzhen Philosophy and Social Science Planning Project, "Research on the Legal Path of Market Integration in the Guangdong-Hong Kong-Macao Greater Bay Area", No. SZ2020B027; Economic and Social Development Research, Base General Project, Liaoning Province, China, "Research on the Legal Issues regarding Northeast Asian Energy Market Integration", No. 20211sljdybkt-005.

Conflicts of Interest: The authors declare no conflict of interest.

\section{References}

1. Wang, X.J. Research on Legal System of Integrated Management of Coastal Zone; Ocean Press: Beijing, China, 2019 ; pp. 40-41. (In Chinese)

2. Lu, S.B.; Ai, W.Z. (Eds.) Research on Integrated Management System and Operation Mechanism of Coastal Zone; Ocean Press: Beijing, China, 2001; pp. 30-35. (In Chinese)

3. Narcise, C.I.; Padayao, D. Harnessing the Power of an Informed Public for Coastal Management. In Local Contributions to Global Sustainable Development Agenda: Case Studies in Integrated Coastal Management in the East Asian Seas Region; Partnerships in Environmental Management for the Seas of East Asia (PEMSEA) and Coastal Management Center (CMC): Quezon City, Philippines, 2018; pp. 111-120.

4. Rahman Khan, M.A. Sustainable Coastal Zone Management: Need for a Holistic Approach for Bangladesh. J. Manag. Sustain. 2020, 10, 112-120.

5. Murari, K.S. Coastal Zone Management: Resolving Climate Change Issues through a Statutory Framework. J. Manag. Sustain. 2016, 6, 114-127. [CrossRef]

6. Batista, C.M.; Montero, O.P. Inquiry into Land-Use Planning and Integrated Coastal Zone Management: The Cuban Experience. Ocean Yearb. 2012, 26, 509-532. [CrossRef]

7. Armstrong, J.M.; Ryner, P.C. United States Marine Management; Ocean Press: Beijing, China, 1986; pp. 62-75.

8. Queffelec, B.; Maes, F. Improving Sea-Land Management by Linking Maritime Spatial Planning and Integrated Coastal Zone Management: French and Belgian Experiences. Ocean Yearb. 2013, 27, 147-170. [CrossRef]

9. Puthucherril, T.G. Adapting to Climate Change and Accelerated Sea-Level Rise through Integrated Coastal Zone Management Laws: A Study of the South Asian Experience. Ocean Yearb. 2012, 26, 533-584. [CrossRef]

10. Dong, Y.; Jiang, M.Z. The Experience Learned from Integrated Coastal Zone Management in Implementing the Strategy of Land and Sea Integration in China. J. Ocean Univ. China 2012, 4, 15-20. (In Chinese)

11. Claire, J.; Karen, E.M.D. Implementing the EU Communications and the EU Recommendation on Integrated Coastal Zone Management: A Study Developing a Model Series of Indicators to Evaluate the Effectiveness of the Integrated. Eur. Energy Environ. Law Rev. 2008, 17, 31-62. 
12. Shelburne, J.M. Shore Protection for a Sure Tomorrow: Evaluating Coastal Management Laws in Seven Southeastern States. Sea Grant Law Policy J. 2020, 10, 130.

13. Chen, S.; Ding, H. On the Legal Nature of Beach. J. Liaoning Norm. Univ. 2000, 9, 21-23. (In Chinese)

14. Rowberry, R.; Hanano, I.; Freedman, S.M.; Wilco, M.; Kline, C. Coastal Cultural Heritage Protection in the United States, France and the United Kingdom. J. Comp. Urban Law Policy 2019, 3, 1-62.

15. Reiblich, J.; Wedding, L.M.; Hartge, E.H. Enabling and Limiting Conditions of Coastal Adaptation: Local Governments, Land Uses, and Legal Challenges. Ocean Coast. Law J. 2017, 22, 156-194.

16. Communication from the Commission-Report to the European Parliament and the Council: An Evaluation of Integrated Coastal Zone Management (ICZM) in Europe Brussels, 7.6.2007 COM (2007) 308 Final and Directive 2014/89/EU of the European Parliament and of the Council of 23 July 2014 Establishing a Framework for Maritime Spatial Planning. Available online: https:/ / ec.europa.eu/environment/iczm/pdf/evaluation_iczm_report.pdf (accessed on 9 April 2021).

17. Law of the People's Republic of China on the Administration of Sea Areas. Available online: http://www.npc.gov.cn/wxzl/ gongbao/2001-10/29/content_5277076.htm (accessed on 7 April 2021).

18. Law of the People's Republic of China on Ports. Available online: http://www.chinalaw.gov.cn/Department/content/2019-01/ 17/592_227072.html (accessed on 9 April 2021).

19. The Website of the Central People's Government of the PRC. Available online: http://gc.mnr.gov.cn/201806/t20180614_1795724. html (accessed on 8 July 2021).

20. Dongying City National People's Congress, the Regulations on the Protection of Coastal Zone in Dongying City. Available online: http:/ / renda.dongying.gov.cn/lifagongzuo/difangxingfagui/2019-12-09/3965.html (accessed on 6 April 2021).

21. Shandong Has Legislated to Protect the Coastal Zone, Covering All Seven Coastal Cities. Available online: https://www.sohu. com/a/363814448_114775 (accessed on 5 April 2021).

22. Regulations of Zhoushan City on the Administration of National Marine Special Reserve. Available online: http:/ / zssfj.zhoushan. gov.cn/art/2020/3/6/art_1561230_42161361.html (accessed on 9 April 2021).

23. Regulations of Guangxi Zhuang Autonomous Region on the Protection of Uninhabited Islands. Available online: http://hyj.gxzf. gov.cn/ztzl/pfzlxc/t3474168.shtml (accessed on 9 April 2021).

24. OCRM, Coastal Zone Management Program. US Office of Ocean and Coastal Resource Management. 1972. Available online: https:/ / coast.noaa.gov / czm/act/ (accessed on 20 May 2021).

25. Buckner, M. The Coastal Zone Management Act's Capacity to Spearhead Coastal Adaptation. Hastings West-Northwest J. Environ. Law Policy 2016, 1, 39-84.

26. Wang, H.; Jiang, C.Y. Research on coastal zone management law: From the perspective of California's Coastal Act. Environ. Sustain. Dev. 2020, 4, 92-98. (In Chinese)

27. Megan, M.; Herzog, S.B.H. Combatting Sea-Level Rise in Southern California: How Local Government Can Seize Adaptation Opportunities While Minimizing Legal Risk. Hastings West-Northwest J. Environ. Law Policy 2013, 19, 463.

28. Cao, W.Z.; Wong, M.H. Current status of coastal zone issues and management in China: A review. Environ. Int. 2007, 33, 985-992. [CrossRef] [PubMed]

29. Marine and Coastal Access Act. Available online: https://www.legislation.gov.uk/ukpga/2009/23/contents (accessed on 19 May 2021).

30. The Science Net, Enhance the Resilience of Coastal Zones in Response to Climate Change. Available online: http://news. sciencenet.cn/htmlnews/2020/12/449437.shtm (accessed on 9 April 2021).

31. Dongying Government Network, Report of Dongying Muncipal Ocean Development and Fishery Bureau on the Handling of Proposals at the Fourth Session of the Eighth Municipal CPPCC. Available online: http://www.dongying.gov.cn/art/2020/12/ 3/art_7890110131912.html (accessed on 9 April 2021).

32. Zhang, J.; Wang, J.H.; Cui, W.L.; Zhao, X.S.; Ma, Y. The threat, management practice and work focus of science and technology support in the China coastal zone during the 13th Five-Year: Examples in Qingdao, Dongying and Lianyungang. Mar. Sci. 2015, 39, 1-7. (In Chinese)

33. Ma, Y. Vertical Environmental Management: A Panacea to the Environmental Enforcement Gap in China. Chin. J. Environ. Law 2017, 1, 37-68. [CrossRef]

34. Duff, J. The Voice of Local Authorities in Coastal and Marine Spatial Planning in the Northeast: Insights from the Regional Ocean Planning Process. Sea Grant Law Policy J. 2017, 8, 6-17.

35. Prak, V.; Sally, N. Beach Management in Sihanoukville, Preah Sihanouk, Cambodia for Sustainable Tourism. In Local Contributions to Global Sustainable Development Agenda: Case Studies in Integrated Coastal Management in the East Asian Seas Region; Partnerships in Environmental Management for the Seas of East Asia (PEMSEA) and Coastal Management Center (CMC): Quezon City, Philippines, 2018; pp. 375-388.

36. Harvey, N.; Clarke, B. 21st Century reform in Australian coastal policy and legislation. Mar. Policy 2019, 103, 27-32. [CrossRef]

37. Huang, H.B.; Hui, Y.C.; Zhang, Y.L.; Wang, W. Integrated Coastal Zone Management in Australia and Its Reference to China. Ocean Dev. Manag. 2021, 1, 28-35. (In Chinese)

38. Harvey, N. Combination-Lock Effect Blocking Integrated Coastal Zone Management in Australia: The Role of Governance and Politics. Ocean Yearb. 2016, 30, 1-31. 
39. Wang, S.Q. The Effective Role of Dongying Interagency Coordinating Mechanism for Implementing Integrated Coastal Management Program. In Local Contributions to Global Sustainable Development Agenda: Case Studies in Integrated Coastal Management in the East Asian Seas Region; Partnerships in Environmental Management for the Seas of East Asia (PEMSEA) and Coastal Management Center (CMC): Quezon City, Philippines, 2018; pp. 61-70.

40. Dongying Public Data Open Network. Available online: http://data.dongying.gov.cn/dongying/catalog/8791d3fc79844d76925 dc922c8f96965 (accessed on 8 July 2021).

41. China News Network, Penglai 19-3 Oilfield Accident Investigation and Treatment Report. Available online: http://www. chinanews.com/gn/2012/06-21/3980404_3.shtml (accessed on 6 April 2021).

42. Qingdao Ocean and Fishery Bureau. Qingdao Marine Environment Bulletin. Available online: http:/ / ocean.qingdao.gov.cn/n1 2479801/n28192913/28337806.html (accessed on 6 April 2021).

43. Zou, G.-B.; Zhu, J.-Z. A Study on Comprehensively Developing South China Sea Coastal Zone. Theor. Investig. 2008, 145, 75-77. (In Chinese)

44. Maren, L. Integrated coastal zone management in the People's Republic of China-An assessment of structural impacts on decision-Making processes. Ocean Coast. Manag. 2005, 48, 115-159.

45. Wang, S. Experiences and Lessons from Integrated Coastal Zone Management of Latin American Coastal Areas-Based on a Comparative Study of Coastal Areas between Latin American and Zhejiang Province of China. J. Zhejiang Ocean Univ. 2014, 31, 11-17. (In Chinese)

46. Schiavetti, A.; Manz, J.; dos Santos, C.Z.; Magro, T.C.; Pagani, M.I. Marine Protected Areas in Brazil: An ecological approach regarding the large marine ecosystems. Ocean Coast. Manag. 2013, 76, 96-104. [CrossRef]

47. Reiblich, J.; Hartge, E.H. The Forty-Year-Old Statute: Unintended Consequences of the Coastal Act and How They Might Be Redressed. Stanf. Environ. Law J. 2016, 36, 63-88.

48. Reis, J.; Stojanovic, T.; Smith, H. Relevance of systems approaches for implementing Integrated Coastal Zone Management principles in Europe. Mar. Policy 2014, 43, 3-12. [CrossRef]

49. Marten, B. Shipping and Air Pollution: New Zealand's Failure to Ratify Marpol Annex VI. Aust. N. Z. Marit. Law J. 2016, 30, 90-98.

50. Yang, J.C. Working Together to Meet Our Shared Responsibility and Build a Community with a Shared Future for Mankind. China Int. Stud. 2019, 79, 5-14.

51. Ayunita, K.; Ruslan, A.; Razak, A.; Halim, H. Legal Arrangements on Management of Coastal Areas in the Region. J. Law Policy Glob. 2020, 95, 113-123. 